\title{
Comparative Genome Organization of Human, Murine, and Feline MHC Class II Region
}

\author{
Naoya Yuhki, ${ }^{1,4}$ Thomas Beck, ${ }^{2}$ Robert M. Stephens, ${ }^{3}$ Yoko Nishigaki, ${ }^{2}$ \\ Kymberly Newmann, ${ }^{1}$ and Stephen J. O'Brien ${ }^{1,4}$ \\ ${ }^{1}$ Laboratory of Genomic Diversity, National Cancer Institute-Frederick, Frederick, Maryland 21702, USA; ${ }^{2}$ Intramural \\ Research Support Program (IRSP), SAIC-Frederick, Frederick, Maryland 21702, USA; ${ }^{3}$ Advanced Biomedical Computing \\ Center, IRSP, SAIC-Frederick, Frederick, Maryland 21702, USA
}

\begin{abstract}
To study comparative molecular dynamics in the genesis of the major histocompatibility complex (MHC), we determined a complete nucleotide sequence spanning 758,291 bp of the domestic cat (Felis catus) extended and classical class II region. The feline class II MHC includes 44 genes (31 predicted to be expressed) which display DNA sequence homology and ordered gene synteny with human $H L A$ and mouse $H 2$, in extended class II and centromere proximal regions (DM to $D O$ ) of the classical class II region. However, remarkable genomic alterations including gene gain and loss plus size differentials of $250 \mathrm{~kb}$ are evident in comparisons of the cat class II with those of human and mouse. The cat MHC lacks the entire DQ region and retains only relict pseudogene homologs of DP genes, compensated by expansion and reorganization of seven modern DR genes. Repetitive gene families within the feline MHC comprise $35 \%$ of the feline $\mathrm{MHC}$ with very different density and abundance of GC levels, SINES, LINES, STRs, and retro-elements from the same repeats in human and mouse MHC. Comparison of the feline MHC with the murine and human MHC offers a detailed view of the consequences of genome organization in three mammalian lineages.
\end{abstract}

The vertebrate major histocompatibility complex (MHC) offers an unusual opportunity for comparative genomics, as it consists of a chromosomally linked community of over 100 expressed genes, nearly half having a defined role in immune defenses. A complete sequence of human HLA (3.6 Mb), chicken $B$-locus ( $92 \mathrm{~kb})$, and a partial mouse $H 2$ sequence $(4.0$ $\mathrm{Mb}$ ) have been determined (Kaufman et al. 1999; The MHC Sequencing Consortium 1999; Shiina et al. 1999; Stephens et al. 1999; Yu et al. 2000; Takada et al. 2003; L. Rowen, pers. comm.). Initial comparisons reveal remarkable differences in gene inclusion, gene order, and sequence divergence, likely driven by natural selective pressures of infectious disease outbreaks in the ancestors of these species (Doherty and Zinkernagel 1976; Klein 1986; Parham and Ohta 1996; Zinkernagel 1996; Hughes and Yeager 1998; Carrington et al. 1999). A deep understanding of the immunological functions, disease influences, evolutionary constraints, and driving forces of MHC adaptation in several mammalian species provides a fertile venue to discern and interpret adaptive events which predate living vertebrate genomes.

$H L A$, the human MHC, is composed of 224 tightly linked genes, including 128 expressed genes, 96 pseudogenes, and repetitive elements (SINES, LINES, LTRs, and STRs) that comprise nearly $50 \%$ of the sequence (The MHC Sequencing Consortium 1999; Shiina et al. 1999). The mouse MHC, H2, includes 120 expressed genes encoding functions similar to those ascribed to human MHC genes plus various pseudogenes and repeat sequences (Klein 1986; Stephens et al. 1999; Yu et al. 2000; Takada et al. 2003; L. Rowen, pers. comm.).

${ }^{4}$ Corresponding authors.

E-MAIL obrien@ncifcrf.gov; FAX (301) 846-6327. E-MAIL yuhki@ncifcrf.gov; FAX (301) 846-1909.

Article and publication are at http://www.genome.org/cgi/doi/10.1101/ gr.976103. Article published online before print in May 2003.
Both human and mouse MHC show linked segments of five subregions named for the individual gene families and ordered as follows from the centromere (size of the human subregion): (1) extended class II (300 kb), (2) classical class II (850 $\mathrm{kb})$, (3) class III (700 kb), (4) classical class I (1800 kb), and (5) extended class I (1000 kb). Within each MHC genomic region, however, there are significant differences between the two species. For example, class I homologs within human or within mice are more orthologous to each other than they are to homologs between the two species. In addition, the many pseudogenes are found predominantly in class I and II regions and are virtually absent in the MHC central (class III) region.

The chicken MHC, $B$-locus, presents a "minimal essential MHC" disposition extending $92 \mathrm{~kb}$ and including just 19 functional genes, 12 of which share homologs in the human and mouse MHC (class II $\beta$, tapasin, class II $\beta$, Ring 3, DM $\alpha$, $D M \beta, D M \beta$, class I, Tap1, Tap2, class I, C4; Kaufman 1999). The order of the chicken $B$-locus gene segments is different from those of human and mouse, and the relative compactness of the chicken MHC ( $\sim 5 \%$ of the human MHC) raises the possibility that the ancestral vertebrate MHC was smaller (like the chicken's) and was expanded during the mammalian radiations.

The MHC class II region is of particular interest because very many of the $\sim 40$ genes included are specifically involved in antigen processing and presentation to the T-cell receptors. The class II region shows evidence of rapid adaptive duplications and deletions as well as allele and haplotype polymorphism within and between human and mouse species. Here we present the complete 758,291-bp sequence of the feline MHC class II region, including the extended and classical class II regions. The cat was chosen to provide comparative MHC sequence from a third order of placental mammals, Carnivora, to augment comparative genomic analysis in domes- 
tic cats (O'Brien et al. 1997, 1999; Murphy et al. 2000) and the Felidae Family (Johnson and O'Brien 1997; Pecon-Slattery and $\mathrm{O}^{\prime}$ Brien 1998) as well as to contribute a powerful genomic tool to develop immunogenetic insight into feline hereditary (http://www.angis.org.au/Databases/BIRX) and infectious disease models, for example, feline leukemia virus (Hoover and Mullins 1991), feline immunodeficiency virus (Pederson et al. 1987), and feline infections peritonitis virus (Andrew 2000).

\section{RESULTS}

A composite 758,291-bp sequence was obtained from five PAC (f20, f23, 6B1, f2, and g7) and four BAC clones (186b21, 102h1, 463h11, and 160a17) which spanned the extended and classical class II region of the domestic cat. Forty-four coding genes were identified by GENESCAN and BLASTP algorithms from the genes HSET (centromeric extreme of extended class II) to BTLII (telomeric of class II region). A description of the function and characteristics of each class II region gene is given in Table 1 . A molecular sequence identity map which compares the feline class II sequence with the human sequence to identify gene homologs, exons, introns, and other genomic features is presented in Figure 1. A comparative alignment of genes found in human, cat, and mouse class II regions is illustrated in Figure 2.

Comparison of the gene organization of the MHC class II region between the mouse, domestic cat, and human indicates size differences of $\sim 250 \mathrm{~kb}$ among these three species (Fig. 2). The sizes of the MHC class II region are $495 \mathrm{~kb}, 758$ $\mathrm{kb}$, and $998 \mathrm{~kb}$ in the mouse, domestic cat, and human, respectively. These size differences appear to reflect both the presence/absence of genes plus moderate differences in gene density in each MHC. The observed gene densities were one gene every $13.7 \mathrm{~kb}, 17.2 \mathrm{~kb}$, and $18.1 \mathrm{~kb}$ in the mouse, domestic cat, and human MHC class II regions, respectively.

The feline extended class II region includes 16 genes (Table 1, Fig. 2). The order of the 16 feline genes is identical to that in human, indicating retention of an ancestral gene order for these genes. The cat MHC contains a single gene RPS28 (40s ribosomal protein S28) between the HSET and DAXX loci, which is absent in human. Three pseudogenes (RPL12-L, $R P L 35 A-L$, and BING3) and one functional gene (APT-2), all absent in cat, occupy this same region in the human MHC. Both segments are absent in mouse, perhaps indicating a Primate- and Felidae-specific gene segment transposition into this region. The mouse extended class II region is also missing a segment that specifies [TATSF1-ZNFL] in human and TATSF1 alone in cat. In that position, the murine MHC includes a stretch of two class I region genes [H2K2, H2K1].

The feline classical class II region contains 28 genes. Of these, 19 are homologous to human MHC homologs whereas three genes, namely GAPDH (glyceraldehyde 3'-phosphate dehydrogenase), SURF3 (L7a ribosomal protein like gene), and $v$-ATPase (vacuolar ATP synthetase) are transposed pseudogenes related to genes located on human chromosomes 12p13 (GAPDH), 9q34 (SURF3), and 3p, 5, 6p21.3 MHC class III region, and 8q22.3 ( $v$-ATPase). In addition, the cat class II region includes three LINE1 reverse transcriptase genes (Smit 1999) and three open reading frames (X) of unknown function (Table 1). Four multigene segments of the human MHC are missing in the feline MHC (labeled A-D in Fig. 2): (A) [RPL12-L, RPL35A-L,APT2, BING3], (B) [COLIIA2P,DPA2, DPB1, RPL32-L,DPA1], (C) [HLA-Z1,RING14,IPP2,RING8], and (D) the entire $D Q$ gene family region $[D Q B 2, D Q A 2$,
$D Q B 3, C O X 3 C L, G L N-t R N A, D Q B 1, D Q A 1]$. The feline DR region consists of four $D R B$ genes and three $D R A$ genes compared to the human's one DRA and two to five $D R B$ genes. The feline $D R$ region genes do not display definitive sequence orthology to the human counterparts, and their gene order is rearranged to suggest a history of duplication and inversion events during Carnivora evolutionary history (see below).

The mouse extended class II region displays a high degree of gene sequence and syntenic homology to the human and cat regions (Fig. 2). The single exception is the placement of $H-2 K 1$ and $H-2 K 2$ class I homologs in a position occupied by two pseudogenes [TAT-SF1 and ZNF-L] in human and one pseudogene, TAT-SF1, in the cat (see bracket E in Fig. 2). The mouse classical class II region shows clear gene sequence and order homology to the human/cat region spanning 11 genes (from $\mathrm{Pb}$ to Tap2 except $\mathrm{Mb} 2$ ). Beyond Tap2 however, there is very limited homology except for distant similarity of $E b 1$, $E b 2, E a$ to $D R$ and $A b 2, A b 1, A a$ to $D O / D Q$ region genes of human and cat. The divergence of mouse class II sequence is striking in the face of more parallel cat/human comparisons and may reflect macro-evolutionarily reorganization/ divergence events in the history of rodent species.

Dot plot analyses (Sonnhammer and Durbin 1995) between the domestic cat sequence and a corresponding sequence of human class II region $(997,836 \mathrm{bp})$ showed clearcut conserved and nonconserved regions between the two species' MHC class II sequences (Fig. 3A). Two long stretches of conserved sequences between cat and human class II region were found; one in the extended class II region $(\sim 250 \mathrm{~kb})$ and a second in the classical class II region $(\sim 220 \mathrm{~kb})$. Upon close inspection using PIPmaker (Fig. 1; Schwarz et al. 2000), the two highly conserved stretches were shown to arise from clustered exonic sequences. In the first, retinoic acid $X$ receptor $\beta$ gene $(R X R B)$ and collagen type $11 \alpha 2$ domain (COL11A2) coding gene have 70 predicted exons in a $40-\mathrm{kb}$ nucleotide sequence in the extended class II region with more than $75 \%$ sequence identity between cat and human sequences (Fig. 1). Similarly, 31 conserved exons included in four genes (LMP2, TAP1, LMP7, TAP2) were clustered within a 30-kb segment of the classical class II region (Fig. 1). These two conserved gene stretches were interrupted by a nonconserved $100 \mathrm{~kb}$ of DP subregion. The $100-\mathrm{kb}$ stretch of the human sequence which encodes $D Q$ subregion was completely missing in the cat sequence.

A dot plot analysis (Sonnhammer and Durbin 1995) of human $(234 \mathrm{~kb})$ and cat DR subregions $(266 \mathrm{~kb})$ detected at least three cat DRB homology segments spanning 15- to 30-kb sequences and three cat $D R A$ signals spanning $15-\mathrm{kb}$ sequences (Fig. 3B). Self-dot plot analysis of cat $D R$ subregion revealed three $15-\mathrm{kb} D R B$ gene repeats, three $15-\mathrm{kb} D R A$ gene repeats, plus two $30-\mathrm{kb}$ repeats including both $D R B$ and $D R A$ genes (Fig. 3C). These homology signals plus the observation that human $D R B$ paralogs and feline $D R B$ paralogs have equivalent amino acid sequence similarity within the two species $(88 \%-94 \%$ in cat $D R B 1,3,4$ vs. 88 to $93 \%$ in human $D R B 1,3,4,5)$, as is apparent between the species $(80 \%-82 \%$ cat vs. human), would suggest the occurrence of duplication subsequent to split of primate and carnivore and reordering of the $D R B$ and $D R A$ gene in the two ordinal lineages. A parsimonious interpretation for the development of the feline DR gene order is illustrated in Figure 4.

Comparative analysis of interspersed repeat sequences in the MHC class II regions among human, domestic cat, and mouse indicated that five types of interspersed repeats,

\section{Genome Research}


Table 1. Genes and Predicted Protein Products From HSET to BTLII of the Cat MHC Class II Region

\begin{tabular}{|c|c|c|c|c|c|c|c|}
\hline \multirow[b]{2}{*}{ Gene } & \multirow{2}{*}{$\begin{array}{l}\text { Functional/physiological properties/other } \\
\text { name/structure }\end{array}$} & \multirow{2}{*}{$\begin{array}{l}\text { Size } \\
\text { (bp) }\end{array}$} & \multirow{2}{*}{$\begin{array}{l}\text { Predicted } \\
\text { protein } \\
\text { size }(a a)\end{array}$} & \multirow{2}{*}{$\begin{array}{l}\text { No. of } \\
\text { exons }\end{array}$} & \multirow{2}{*}{$\begin{array}{c}\text { Distance } \\
\text { to next } \\
\text { gene (bp) }\end{array}$} & \multicolumn{2}{|c|}{$\begin{array}{l}\% \text { aa sequence } \\
\text { similarity }\end{array}$} \\
\hline & & & & & & Human & Mouse \\
\hline \multicolumn{8}{|c|}{ Extended Class II Region } \\
\hline HSET & $\begin{array}{l}\text { Kinesin motor protein-related, kifc, KNSL2, } \\
\text { kinesin-like protein } 2\end{array}$ & $>13226$ & $>657$ & $>10$ & 12643 & 91 & 83 \\
\hline RPS28 & Component of S28 of ribosome & 1861 & 103 & 2 & 46489 & 55 & 55 \\
\hline$D A X X$ & Fas binding protein, apoptosis through c-Jun & 3197 & 748 & 7 & 1754 & 91 & 80 \\
\hline BING1 & Zinc finger domain & 1907 & 635 & 1 & 959 & 95 & 88 \\
\hline TAPASIN & $\begin{array}{l}\text { Ig superfamily, associate with class I antigen during } \\
\text { peptide loading }\end{array}$ & 11062 & 488 & 9 & 2207 & 85 & 75 \\
\hline RGL2 & Rat guanine nucleotide dissociation factor & 6658 & 664 & 15 & 3121 & 94 & 92 \\
\hline BING4 & WD40 domain & 7638 & 612 & 15 & 709 & 93 & 87 \\
\hline B3GALT4 & $\beta$ 1,3-galactosidase-4 & 1152 & 378 & 2 & 1000 & 86 & 81 \\
\hline RPS18 & Component of $\mathrm{S} 18$ of ribosome, KE3 & 5011 & 152 & 6 & 438 & 100 & 100 \\
\hline ARE1 & $\begin{array}{l}\text { Yeast sac2 homolog, suppressor of actin mutant } 2 \text {, } \\
\text { Sacm2l, coiled coil structure }\end{array}$ & 15145 & 702 & 17 & 28038 & 99 & 93 \\
\hline TAT-SF1 & HIV1 transcriptional elongation factor, pseudogene & ND & ND & 1 & ND & ND & ND \\
\hline RING1 & Ring finger protein, polycomb group protein & 2351 & 307 & 6 & 4129 & 99 & 98 \\
\hline KE6 & $\begin{array}{l}\text { Steroid dehydrogenase-like protein (estradiol } 17 \\
\beta \text {-dehydrogenase 8) }\end{array}$ & ND & 149 & 4 & ND & 61 & 60 \\
\hline KE4 & $\begin{array}{l}\text { Transmembrane protein with histidine-rich charge } \\
\text { clusters }\end{array}$ & 4516 & 193 & 4 & 858 & 83 & 82 \\
\hline$R X R B$ & Retinoid $X$ receptor, $\beta$ & 5559 & 475 & 10 & 2515 & 100 & 97 \\
\hline COL11A2 & Type 11 collagen $\alpha 2$ & 28027 & 1624 & 60 & 7492 & 97 & 95 \\
\hline \multicolumn{8}{|c|}{ Classical Class II Region } \\
\hline$D P B$ & Class II antigen, $\beta$ chain, pseudogene & 22891 & 317 & 5 & 2597 & 60 & ND \\
\hline DPA & Class II antigen, $\alpha$ chain, pseudogene & 8678 & 235 & 5 & 5075 & 74 & ND \\
\hline$x$ & Unknown function & 9161 & 205 & 2 & 10553 & ND & ND \\
\hline$D N A$ & $\begin{array}{l}\text { DOA, heterodime with DOB in pre-B cells, peptide } \\
\text { loading for class II antigen at low PH }\end{array}$ & 9622 & 250 & 5 & 15757 & 86 & 77 \\
\hline RING3 & Nuclear-localized, serine-threonine kinase, frg-1 & 13809 & 1093 & 17 & 10773 & 98 & 95 \\
\hline$D M A$ & $\begin{array}{l}\text { Nonclassical class II antigen, } \alpha \text { chain, peptide loading } \\
\text { for class II antigen }\end{array}$ & 3926 & 260 & 5 & 9876 & 86 & 81 \\
\hline$D M B$ & $\begin{array}{l}\text { Nonclassical class II antigen, } \beta \text { chain, heterodimer } \\
\text { with DMA, peptide loading for class II antigen }\end{array}$ & 9387 & 279 & 5 & 16548 & 82 & $\begin{array}{l}70(\mathrm{Mb} 1) \\
71(\mathrm{Mb} 2)\end{array}$ \\
\hline V-ATPase & Vacuolar ATPase, pseudogene & 9952 & 229 & 4 & 21688 & 70 & 70 \\
\hline LINE1 & Reverse transcriptase homolog & 464 & 154 & 1 & 15606 & 59 & 48 \\
\hline LMP2 & $\begin{array}{l}\text { Proteosome subunit to cleave peptides for class I } \\
\text { antigen }\end{array}$ & 3057 & 196 & 5 & 2528 & 92 & 91 \\
\hline TAP1 & Transporter for antigen processing & 7279 & 713 & 11 & 1822 & 82 & 75 \\
\hline LMP7 & $\begin{array}{l}\text { Proteosome subunit to cleave peptides for class I } \\
\text { antigen }\end{array}$ & 2875 & 276 & 5 & 2591 & 82 & 85 \\
\hline TAP2 & Transporter for antigen processing & 9852 & 702 & 11 & 3451 & 79 & 77 \\
\hline LINE1 & Reverse transcriptase homolog & 1039 & 198 & 2 & 5980 & 50 & 45 \\
\hline$D O B$ & $\begin{array}{l}\text { Nonclassical class II antigen, } \beta \text { chain, } \mathrm{H} 2-\mathrm{IAB} 2 \text { in } \\
\text { mouse }\end{array}$ & 18247 & 209 & 4 & 1119 & 72 & 67 \\
\hline LINE1 & Reverse transcriptase homolog & 18237 & 222 & 4 & 14603 & 70 & 68 \\
\hline DRB4 & Class II antigen, $\beta$ chain & 12470 & 266 & 5 & 33292 & 81 (DRB3) & 78 (Eb1) \\
\hline GAPDH & Glycerol aldehyde phosphodehydrase, pseudogene & ND & ND & ND & ND & ND & ND \\
\hline DRB1 & Class II antigen, $\beta$ chain & 10009 & 266 & 5 & 14668 & 81 (DRB3) & 78 (Eb1) \\
\hline DRA1 & Class II antigen, $\alpha$ chain & 2684 & 254 & 5 & 40740 & 91 & 81 \\
\hline SURF3 & L7a ribosomal protein, pseudogene & ND & ND & 1 & $\begin{array}{l}\text { inside intron } \\
1 \text { of DRB2 }\end{array}$ & ND & ND \\
\hline DRB2 & $\begin{array}{l}\text { Class II antigen, } \beta \text { chain, intron } 1 \& \text { exon } 2 \text { gene } \\
\text { fragment, pseudogene }\end{array}$ & ND & 89 & 1 & ND & ND & ND \\
\hline$D R B 3$ & Class II antigen, $\beta$ chain & 9680 & 294 & 5 & 10790 & 81 (DRB3) & 80 (Eb1) \\
\hline$x$ & Unknown function & 179 & 266 & 1 & 2666 & ND & ND \\
\hline DRA2 & Class II antigen $\alpha$ chain & 2684 & 254 & 5 & 24414 & 91 & 81 \\
\hline$x$ & Unknown function & 176 & 58 & 1 & 6120 & ND & ND \\
\hline DRA3 & Class II antigen $\alpha$ chain & 3132 & 254 & 5 & 19743 & 92 & 83 \\
\hline BTLII & Butyrophilin-like gene, immunoglobulin superfamily & $>26700$ & $>392$ & $>6$ & ND & 75 & 65 (NG9) \\
\hline
\end{tabular}

namely SINEs, LINEs, LTR transposons, short tandem repeats (STRs), and DNA transposons were common to all three species. There were however notable differences in the proportion of the repeat sequences in the three species' MHC class II regions (Table 2). Human ALU-SINE repeats (Rowold and Herrera 2000) occupy threefold greater sequence density compared to human LINE repeats in the extended class II density region (27\% for SINEs and $6.8 \%$ for LINEs). In contrast, hu- 
A
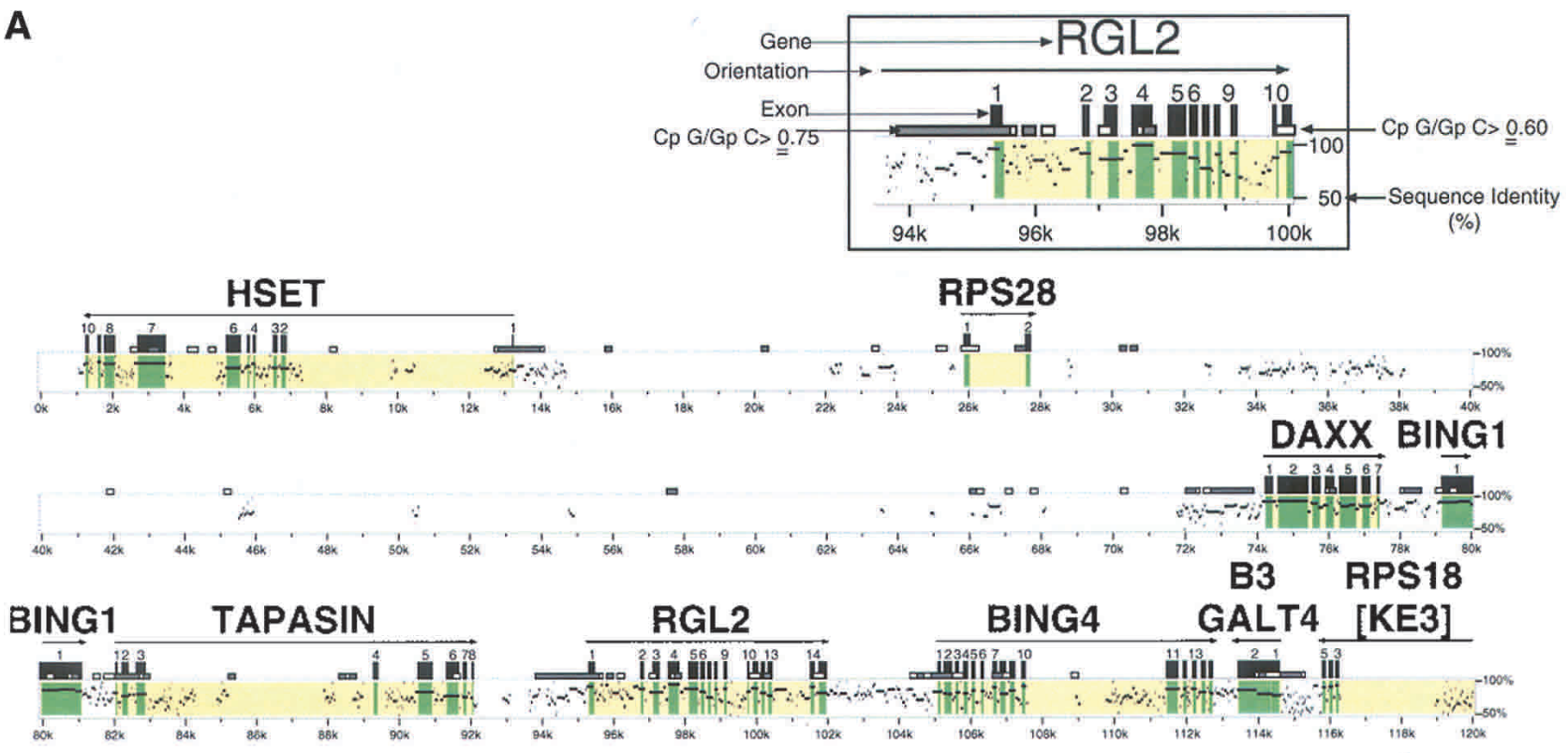

\section{RGL2}

BING4

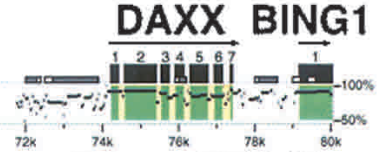

B3 RPS18

\section{ARE1}

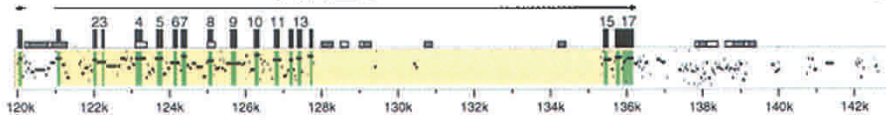

\section{TAT-SF1}

\section{RING1 KE6 KE4 RXRB}

COL11A2

$\therefore=0$

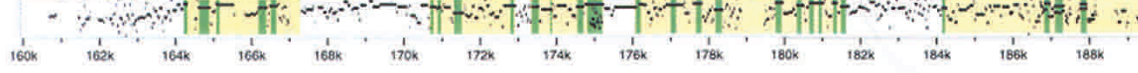

\section{COL11A2}

\section{DPB}

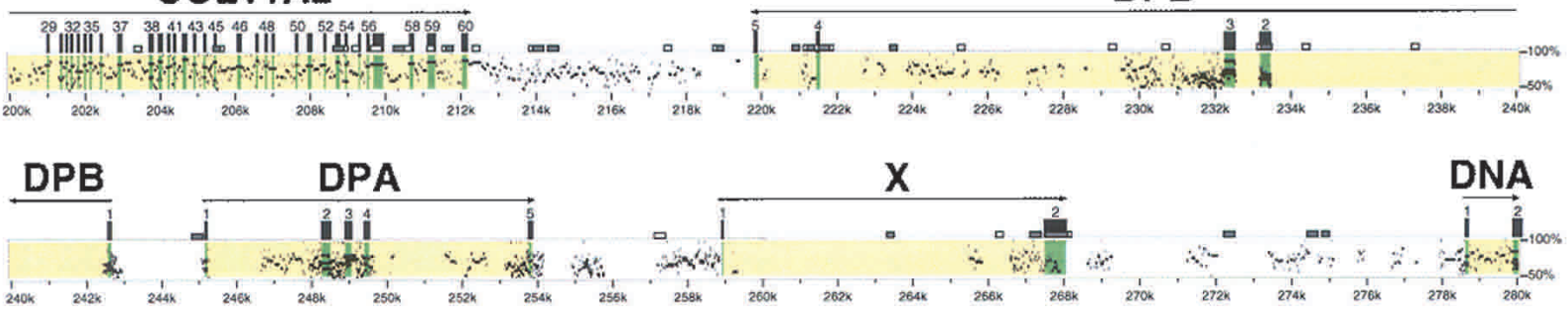

\section{DNA}

\section{RING3}

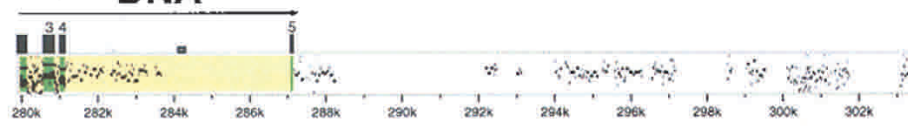

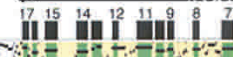

GALT4

[KE3] 


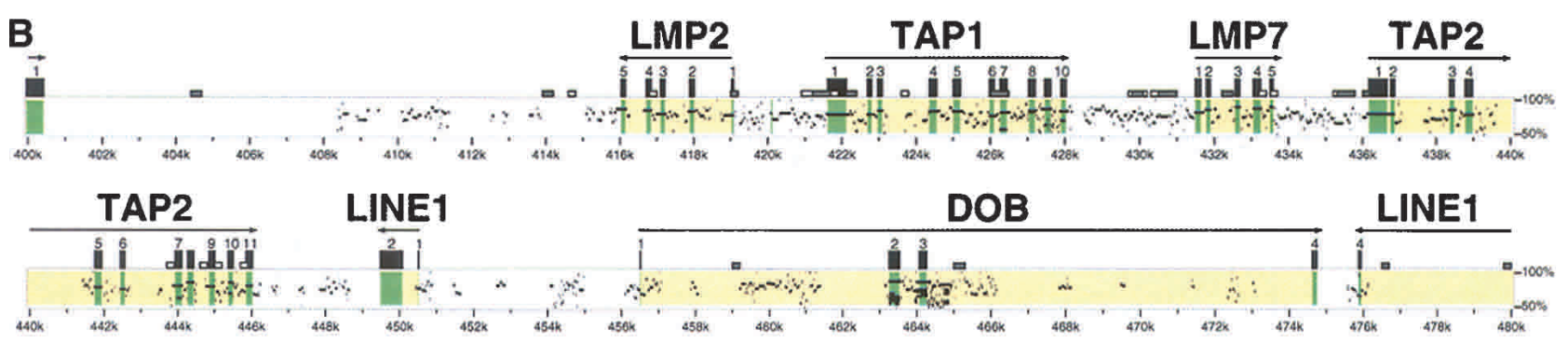

\section{LINE1}

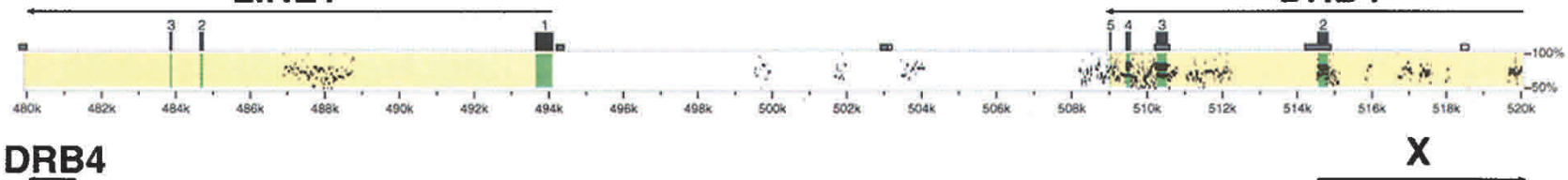

\section{DRB4}
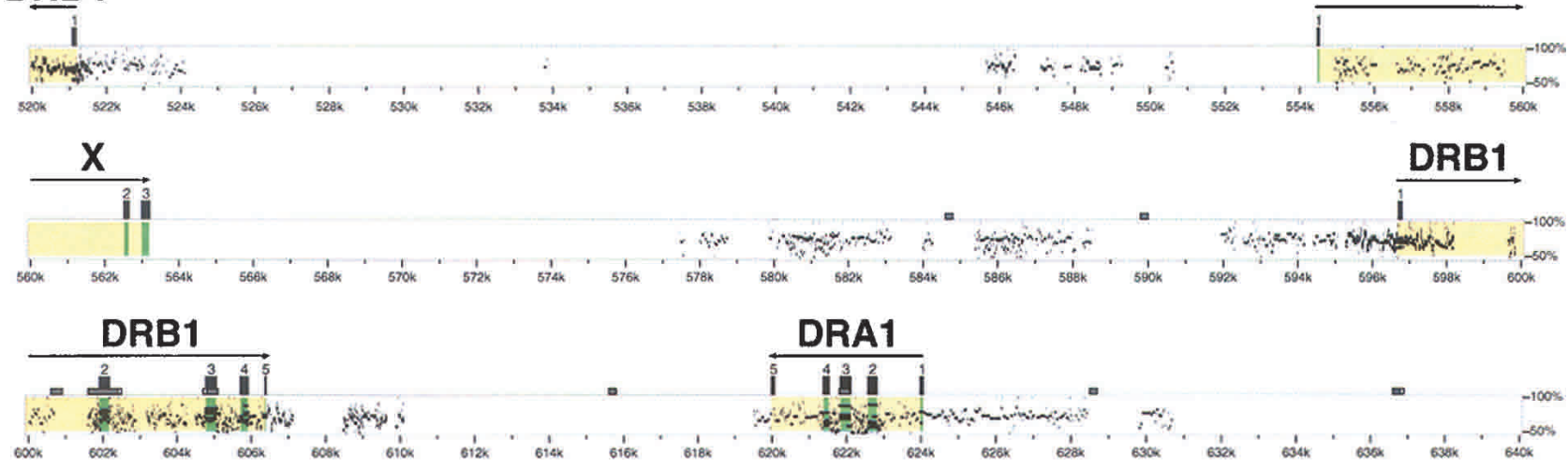

\section{DRB2}
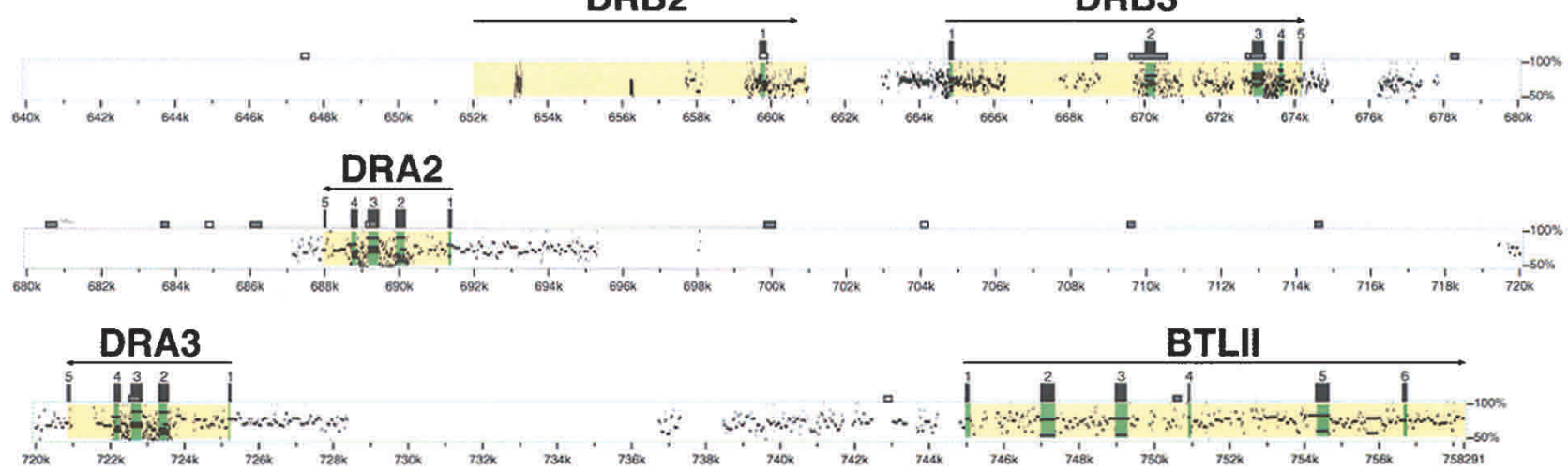

Figure 1 Identity Plot (PIP) of cat and human MHC class II DNA sequence (Schwartz et al. 2000). A description of each gene, its size (initiation codon to termination codon), and percent deduced amino acid sequence identity to human and mouse is given in Table 1 . " $X$ " indicates open reading frame predicted by Genscan (Burge and Karlin 1997), but not yet confirmed by transcript identification.

man LINE repeats were twice as common in the classical class II region compared to $A L U$-SINE repeats (23\% for LINEs and 9.7\% for SINEs). Human SINE repeats were twice as dense in the extended class II region as their counterpart SINEs in mouse and cat (Daniels and Deininger 1985; Slattery et al. 2000). The LINE elements of human and cat are 10 times more dense in the extended class II region and six times more dense in the classical class II region than LINEs in the same mouse regions. Cats had 3-6 times fewer endogenous retroviral long terminal repeat $(L T R)$ sequences across their MHC compared to mouse or human, whereas mice showed a 4-8-fold reduction in DNA transposon elements relative to human and cat (Table 2).
The number of STR-microsatellite motifs was highest in the cat (285 loci), lowest in human (149 loci), and intermediate in the mouse (186 loci). The reduction in human was greater when loci with counts of greater than eight perfect repeats (di- and trinucleotide) were considered. The frequency of dinucleotide repeats in the human class II sequence was $\sim$ three times lower than in domestic cat and mouse. Trinucleotide repeats with more than eight core repeats were not found in the human sequence; there were some in cat and mouse sequence.

\section{DISCUSSION}

The complete MHC class II region sequence analysis allowed a direct comparison among species of three mammal orders 


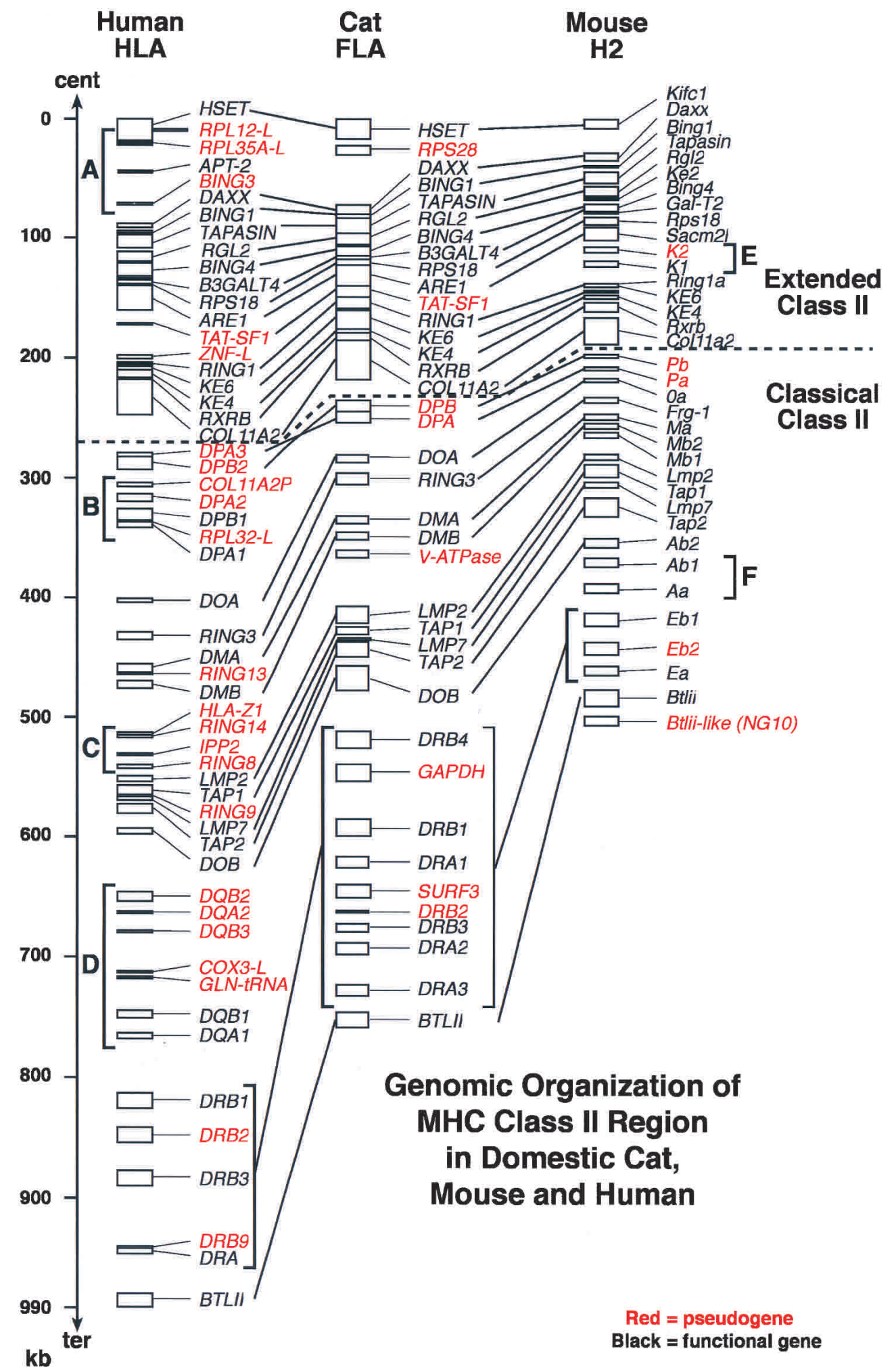

Figure 2 Comparative genomic organizations of the MHC class II region in mouse, domestic cat, and human. Brackets $(A-C)$ indicate gene segments in human, but absent in mouse and cat. $(D) A$ human gene segment absent in cat. $(E) A$ mouse gene segment absent in human and cat. ( $F$ ) A mouse segment absent in cat. Three feline LINE1 elements and unconfirmed open reading frames (X) shown in Table 1 are not included in the three species' maps. Sequences with accession nos. AF110520, AF100956, AF027865, AF050157 for mouse and Z97183, Z97184, AL031228, AL049813, X02228, X03100, Z95437, Z81310, Z99705, Z84497, Z96104, X87344, Z84490, AL049729, Z80899, U92032, Z84489, AL049740, Z84814, AL034394 for human were used for this figure. 

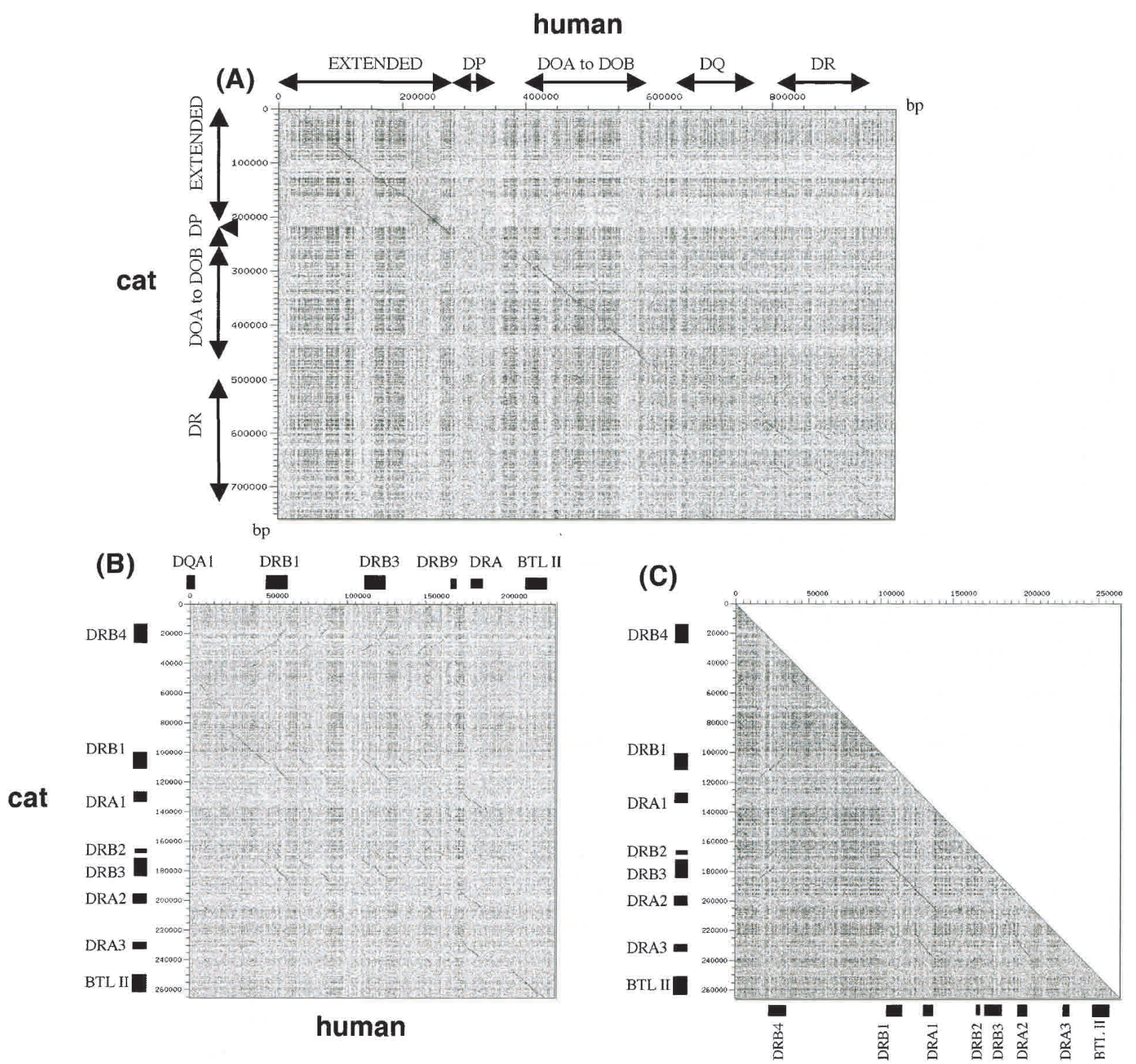

Figure 3 (A) Dotter dot plot comparisons (Sonnhammer and Durbin 1995): human MHC class II sequence (997,836 bp, horizontal) vs. domestic cat MHC class II sequence $\left(758,291 \mathrm{bp}\right.$, vertical). Arrow bars indicate positions of each subregion. Lines with $45^{\circ}$ angle indicate homologous sequence stretches between human and cat class II sequences with a same/reverse orientation. (B) Human DR subregion sequence (235 kb, horizontal) vs. cat $D R$ subregion sequence (266 kb, vertical). (C) Self-sequence analysis in cat $D R$ subregion to identify large repeat sequences, including gene duplication.

which last shared a common ancestor around 80 million years ago. The data showed a remarkable conservation of nucleotide sequence and gene organization, especially between human and domestic cat. This conservation was evident in the extended class II region and in portions of the classical class II region encoding $D O A$ (DNA), RING3 kinase, DMA, B, LMP2, TAP1, LMP7, TAP2, and DOB genes. In contrast, subregions encoding classical class II antigen presenting molecules, $D P$, $D Q$, and $D R$ were thoroughly reorganized in both species. In the human, functioning pairs of $\alpha$ - and $\beta-D P, D O$, and $D R$ genes are maintained, whereas in domestic cat, only $D R$ functional genes were evident.
One pair of $D P B$ and $D P A$ genes was identified in the domestic cat, but several lines of evidence suggest that these are pseudogenes. First, the cat DPA gene had higher sequence similarity (70\%) and gene order syntenic homology to the human DPA2 pseudogene rather than to the functional human DPA1 gene (53\% similarity). Second, the cat DPA gene had a premature termination codon resulting from a single base pair deletion in an extracellular domain coding exon. Third, a direct sequence comparison confirmed evidence that human DPA3 and cat DPA pseudogenes shared similar characteristics of insertion and deletion in the transmembrane and cytoplasmic domains, suggesting that human and cat 


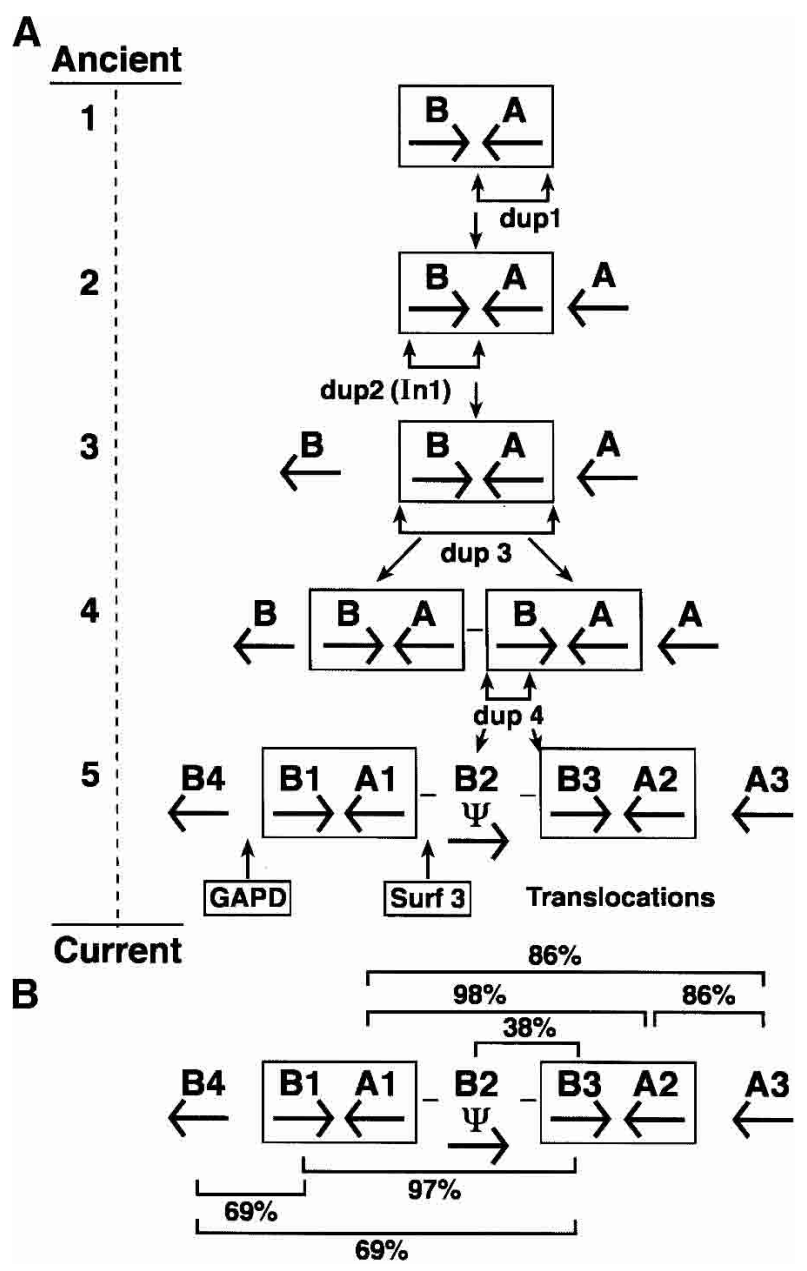

Figure 4 (A) A postulated schema for the origin of feline $D R$ subregion evolution by gene duplication (dup1, dup2, dup3, dup4), inversion (In 1) and pseudogene transpositions. Consider the primitive ancestral occurrence of two $D R$ units: one $D R B$ and one DRA gene arranged in a tail-to-tail fashion on a $30-k b$ segment. Genes within this unit underwent two successive early gene duplications (dup1 and dup2) followed by a third duplication of the $A B$ unit (dup3). A fourth pseudogene $D R B$ duplication (dup4) punctuated by three pseudogene transposition/insertions from disperse autosomal coding loci would account for the disposition and orientation of the DRA and DRB gene family, at least for the presently observed haplotype as illustrated in $B$. (B) Present gene order and orientation of $D R$ genes of the cat. The bars indicate percent nucleotide sequence identity of connected gene sequences. The $97 \%-98 \%$ similarity of the internal B-A blocks indicates that dup 3 was relatively recent.

DPA pseudogenes descended from a common ancestral pseudogene (Verhoeven et al. 1988). Fourth, sequence homology between cat DPB and human DPB1 genes was found only in a portion of transmembrane and cytoplasmic domain coding region, and no homology was found in the extracellular domains between cat $D P B$ and the functional human DPB1 genes (data not shown).

Previous attempts to isolate DQ cDNAs from the domestic cat were unsuccessful (Yuhki and O'Brien 1997), and DQlike signals could not be detected by Southern blotting of cat DNA (Yuhki and O'Brien 1988). In addition, BAC/PAC contig mapping of the domestic cat class II region indicated that the interval between $D O B$ and $D R B 4$ genes was $\sim 60 \mathrm{~kb}$ (Beck et al.
2001). Because the interval between the human $D O B$ and $D R B 1$ is more than $200 \mathrm{~kb}$, the $D Q$ region is either missing or foreshortened in domestic cat MHC class II. The present sequence affirms that the cat MHC lacks the entire DQ subregion. The domestic cat is the first mammalian species to lack the entire $D Q$ region among MHC loci characterized to date, including that of human, mouse, rat, cow, sheep, rabbit, pig, horse, and dog (Takahashi et al. 2000).

The $D R$ subregion in the domestic cat was rearranged by four gene-duplications and one inversion event (Fig. 4). Sequence comparisons between all $\alpha$ - and $\beta$-genes indicated that DRB4 and DRA3 genes were the most divergent from other cat $\beta$ - and $\alpha-D R$ genes sharing $69 \%$ (DRB4 vs. DRB1, $D R B 3)$ and $84 \%$ (DRA3 vs. DRA1, DRA2) nucleotide sequence identities including intron sequences. Both $D R B 4$ and $D R A 3$ genes appear to encode functional $\alpha$ - and $\beta$-proteins based on predicted amino acid sequences (data not shown). Two adjacent pairs of DRB-DRA genes (DRB1-DRA1) and (DRB3-DRA2) are more closely related, sharing $97 \%-98 \%$ nucleotide sequence identity including intron sequences, suggesting that these pairs of genes were generated by a recent gene duplication event (Fig. 4).

Takahashi et al. (2000) reviewed origins and divergence times of class II MHC gene clusters by examining $\alpha$ - and $\beta$-genes in placental, marsupial, and avian species. They concluded that $\alpha$ - and $\beta$-genes in each of $D P, D O, D M, D Q$ and $D R$ class II subregions were established around the time of separation of placental mammals and marsupials, 160-260 million years ago (Takahashi et al. 2000; Eizirik et al. 2001). Most mammalian and marsupial species have $\alpha$ - and $\beta$-genes in these subregions. However, some of the gene clusters were apparently rearranged or deleted in the evolutionary process. For example, the mole rat MHC lacks the entire $D R$ subregion (Nizetic et al. 1987) and contains multiple $\alpha$ - and $\beta$-genes in the DP subregion, whereas the bovine and ovine DP subregion was replaced by new clusters of DI/DY (Stone and MuggliCockett 1990; van der Poel et al. 1990; Wright et al. 1994). The primate DP subregion contains two pairs of $\alpha$ - and $\beta$-genes with at least one pair of functional $D P$ genes, whereas other mammalian DP subregions contain a nonfunctional pair of $\alpha$ - and $\beta$-genes (Takahashi et al. 2000).

The present study reveals that the domestic cat evolutionary lineage has experienced similar large changes in the class II region. The most dramatic change in the domestic cat class II region includes loss of functional $D Q$ and $D P$ genes and expansion of the $D R$ gene family (Figs. 2, 3). Loss of the $D Q$ and $D P$ genes may be the reason for a remarkable immunological "tolerance" seen in cats from several perspectives, including: (1) the lack of cytotoxic antibody production (including IgE) in multiparous cats (Pollack et al 1982; Winkler et al. 1989), (2) very inefficient antibody induction; only 13 of 59 domestic cats (22\%) produced detectable levels of antibodies following allogenic lymphocyte immunization and skin graft transplantation (Winkler et al. 1989), and (3) a remarkable tolerance for allogenic bone marrow and tissue transplants among noninbred cats used in gene therapy protocols (Simonaro et al. 1999; Sun et al. 1999). The critical role of class II gene families in antibody production would support the notion that $D P / D Q$ loss in domestic cats contributes to quantitative diminution of antibody recognition and induction. As a corollary, it is tempting to speculate that the expansion of feline $D R$ genes may reflect an adaptive MHC compensation for the $D P / D Q$ depletion.

The cat MHC class II region maintained a similar level of

\section{Genome Research


Table 2. Distribution of Repetitive Elements in Human, Cat, and Mouse MHC Regions

\begin{tabular}{|c|c|c|c|c|c|c|c|c|c|c|c|c|}
\hline & \multicolumn{6}{|c|}{ Extended class II region } & \multicolumn{6}{|c|}{ Classical class II region } \\
\hline & \multicolumn{2}{|c|}{$\begin{array}{c}\text { human } \\
278,351 \text { bp }\end{array}$} & \multicolumn{2}{|c|}{$\begin{array}{c}\text { cat } \\
232,000 \text { bp }\end{array}$} & \multicolumn{2}{|c|}{$\begin{array}{c}\text { mouse } \\
189,400 \text { bp }\end{array}$} & \multicolumn{2}{|c|}{$\begin{array}{c}\text { human } \\
719,485 \text { bp }\end{array}$} & \multicolumn{2}{|c|}{$\begin{array}{c}\text { cat } \\
526,291 \text { bp }\end{array}$} & \multicolumn{2}{|c|}{$\begin{array}{c}\text { mouse } \\
292,290 \text { bp }\end{array}$} \\
\hline & No. & $\%$ & No. & $\%$ & No. & $\%$ & No. & $\%$ & No. & $\%$ & No. & $\%$ \\
\hline SINES & 295 & 27.0 & 151 & 11.8 & 158 & 11.5 & 293 & 9.7 & 286 & 9.1 & 236 & 10.9 \\
\hline LINEs & 48 & 6.8 & 59 & 12.2 & 7 & 0.5 & 250 & 23.0 & 66 & 23.6 & 30 & 4.3 \\
\hline LTRs & 29 & 6.3 & 14 & 2.1 & 48 & 12.3 & 129 & 11.1 & 32 & 2.1 & 76 & 13.4 \\
\hline DNA transposon & 35 & 2.9 & 26 & 2.7 & 4 & 0.4 & 78 & 3.8 & 40 & 2.1 & 7 & 0.5 \\
\hline STRs $^{\mathrm{a}}$ & 39 & & 97 & & 80 & & 110 & & 188 & & 106 & \\
\hline di & 26 & & 84 & & 59 & & 91 & & 158 & & 98 & \\
\hline tri & 5 & & 6 & & 9 & & 1 & & 9 & & 12 & \\
\hline tetra & 8 & & 4 & & 12 & & 17 & & 17 & & 17 & \\
\hline penta & 0 & & 2 & & 0 & & 1 & & 3 & & 6 & \\
\hline hexa & 0 & & 1 & & 0 & & 0 & & 1 & & 2 & \\
\hline
\end{tabular}

GC content to human HLA in both extended and classical class II regions. The cat class II region maintained $49.1 \%$ and $41.2 \%$ GC levels in the extended and classical regions, respectively, whereas the human $H L A$ class II region maintained $49.9 \%$ and $41.3 \%$ in its same regions, sharing the same character of isochores (H2 and L2; Bernardi 2000a,b). In contrast, the mouse $H 2$ class II region showed nearly identical levels of GC content in the extended (51.7\%) and classical (47.4\%) regions, both categorized as isochore $\mathrm{H} 2$. This observation supports the finding that the GC-poor classical class II region is significantly shorter in mouse than in human (Pavlicek et al. 2002). This may reflect the low copy number of LINE repeats and the high gene density in the mouse MHC class II region. Alternatively, a loss of GC-poor DNA in an ancestral mouse is in agreement with a general propensity of more compact vertebrate genomes to contract their DNA preferentially in the GC-poor regions (Pavlicek et al. 2002). In addition, the distinct levels of interspersed repeats, STRs, and GC levels observed in these three mammalian MHC class II sequences (Table 2) may reflect unique histories of each mammalian genome and their included major histocompatability complex.

\section{METHODS}

\section{PAC/BAC Sequencing Ready Contigs}

A sequence-ready PAC/BAC contig for the entire classical class II region was described elsewhere (Beck et al. 2001). Briefly, this contig was generated by screening domestic cat PAC and BAC (RPCI 86) libraries using homologous MHC CDNA and PCR clones as probes. These DNA clones were then analyzed by restriction enzyme fingerprinting and assembled. Representative clones for a large-scale sequencing were selected in order to minimize the amount of sequencing effort. The BAC/ PAC clones 186b21, 102h1, f20, f23, 463h11, 6B1, 244e2, $\mathrm{f} 2, \mathrm{~g} 7$, and $\mathbf{1 6 0 a 1 7}$ were selected to cover the entire extended and classical class II regions (BAC clones are indicated in bold).

\section{Large-Scale Isolation of PAC and BAC DNAs}

Large-scale isolation of PAC DNA clones was performed using the QIAGEN Large-Construct Kit. Briefly, a single bacteria colony was inoculated into $3 \mathrm{~mL}$ of Superbroth containing 40 $\mu \mathrm{g} / \mathrm{mL}$ kanamycin, and grown overnight with shaking at $37^{\circ} \mathrm{C}$. Then $0.5 \mathrm{~mL}$ of the overnight culture was inoculated into $250 \mathrm{~mL}$ of Superbroth containing $40 \mu \mathrm{g} / \mathrm{mL}$ kanamycin, and shaken at $37^{\circ} \mathrm{C}$ for $3 \mathrm{~h}$ until $\mathrm{A}_{550}$ reached 0.15 . Then 2.5 $\mathrm{mL}$ of $0.1 \mathrm{M}$ IPTG was added to the culture and incubated for $3 \mathrm{~h}$ at $37^{\circ} \mathrm{C}$ until $\mathrm{A}_{550}$ reached 1.5 . Cells were harvested by centrifugation at $5000 \mathrm{~g}$ for $10 \mathrm{~min}$. The bacterial pellet was resuspended in $10 \mathrm{~mL}$ of P1 buffer (QIAGEN Large-Construct Kit), and then $10 \mathrm{~mL}$ of P2 buffer was added, mixed gently, and incubated at room temperature for $5 \mathrm{~min}$. Then $10 \mathrm{~mL}$ of chilled P3 buffer was added, mixed and incubated on ice for $10 \mathrm{~min}$. After centrifugation at $8000 \mathrm{rpm}$ for $15 \mathrm{~min}$ in 2059 Falcon tubes, the clear supernatant was collected and applied to a QIAGEN-tip 500 according to the manufacturer's instructions. Large-scale isolation of BAC DNA was performed essentially as described above except that kanamycin was replaced with $25 \mu \mathrm{g} / \mathrm{mL}$ chloramphenicol, IPTG induction was omitted, and ATP-dependent exonuclease and ATP were added according to the manufacturer's instructions.

\section{Construction of Shotgun Libraries}

Shotgun sequencing libraries were constructed from purified PAC/BAC DNA. Briefly, 20 to $80 \mu \mathrm{g}$ PAC or BAC DNA was nebulized using an Aero-Mist Nebulizer (CIS-US) for 15 to 20 min at 4 psi using argon gas in a total volume of $1.5 \mathrm{~mL}$ containing $35 \mathrm{mM}$ Tris-HCl pH8.0, $15 \mathrm{mM} \mathrm{MgCl}_{2}$, and $25 \%$ glycerol. The size range of sheared DNA fragments was assessed by electrophoresis through $1 \%$ agarose gel. When the size range reached 1.5 to $3.0 \mathrm{~Kb}$, the DNA was precipitated by addition of 0.1 volumes of $3 \mathrm{M} \mathrm{NaOAc}$, pH 7.5 and 2.5 volumes of ethanol by centrifugation at $14,000 \mathrm{rpm}$ for $10 \mathrm{~min}$ in an Eppendorf centrifuge. The DNA pellet was washed with $70 \% \mathrm{EtOH}$ and dried briefly. End structures of randomly sheared DNA fragments were repaired by resuspending sheared DNA fragments in $25 \mu \mathrm{L}$ of TM buffer $(35 \mathrm{mM}$ Tris$\mathrm{HCl}, \mathrm{pH} 8.0,15 \mathrm{mM} \mathrm{MgCl}_{2}$ ), then addition of $10 \mu \mathrm{L}$ of $5 \times$ forward reaction buffer (Gibco BRL), $5 \mu \mathrm{L}$ of $10 \mathrm{mM}$ rATP (Pharmacia Biotech), $7 \mu \mathrm{L}$ of $0.25 \mathrm{mM}$ dNTPs (PE Applied Biosystems), 3 units T4 polynucleotide kinase (Gibco BRL) and 10 units of Klenow fragment DNA polymerase (Gibco $\mathrm{BRL})$ followed by incubation at $37^{\circ} \mathrm{C}$ for $30 \mathrm{~min}$. After fractionation through a $1 \%$ agarose gel, agarose blocks containing DNA fragments ranging in size from 1.5 to $3.0 \mathrm{~Kb}$ were excised and the DNA fragments were electroeluted into dialysis tubing (Gibco BRL) and then ethanol-precipitated as above. The DNA pellet was resuspended in $20 \mu \mathrm{L}$ of TE, and a $10 \mu \mathrm{L}$ aliquot was ligated to $100 \mathrm{ng}$ of pBlueScript KS+ (Stratagene) that had been digested with EcoRV and dephosphorylated 
with calf intestinal alkaline phosphatase, using $1 \times$ T4 DNA ligase buffer and 1 unit T4 DNA ligase at $4^{\circ} \mathrm{C}$ for $16 \mathrm{~h}$. After ethanol precipitation, the DNA ligation products were resuspended in $10 \mu \mathrm{L}$ of $\mathrm{H}_{2} \mathrm{O}$, and a $1 \mu \mathrm{L}$ aliquot was electroporated into $25 \mu \mathrm{L}$ E. coli DH10B cells (Gibco BRL) at $1.6 \mathrm{kV}$. After addition of $975 \mu \mathrm{L}$ of SOC media (Gibco BRL) and incubation for $30 \mathrm{~min}$ at $37^{\circ} \mathrm{C}, 50 \mu \mathrm{L}$ aliquots were spread onto LB agar plates containing $50 \mu \mathrm{g} / \mathrm{mL}$ ampicillin which had been pretreated by spreading $50 \mu \mathrm{L} \mathrm{Xgal}(25 \mathrm{mg} / \mathrm{mL})$ and $10 \mu \mathrm{L}$ of IPTG (100 mM) just before use. The plates were incubated overnight at $37^{\circ} \mathrm{C}$.

\section{High-Throughput Mini-Preparation and Sequencing of Plasmid DNAs}

High-throughput mini-preparations were performed essentially as described by $\mathrm{Ng}$ et al. (1996). Bacterial colonies from the shotgun library were picked using toothpicks and inoculated into a 2-mL 96-well plate containing $1.25 \mathrm{~mL}$ of Superbroth and $50 \mu \mathrm{g} / \mathrm{mL}$ ampicillin and two glass balls $(3.5 \mathrm{~mm}$ in diameter). The plate was incubated overnight at $37^{\circ} \mathrm{C}$ with shaking at $200 \mathrm{rpm}$. Bacterial cells were pelleted by centrifugation in a Sorvall RT 6000 centrifuge at $3000 \mathrm{rpm}$ for $10 \mathrm{~min}$ at $4^{\circ} \mathrm{C}$, the medium was discarded, drained onto a paper towel, and the bacterial pellet was resuspended in $100 \mu \mathrm{L}$ of P1 buffer by vortexing. After addition of $200 \mu \mathrm{L}$ of P2 buffer and gentle mixing, $150 \mu \mathrm{L}$ of chilled P3 buffer was added, rapidly mixed and incubated for $10 \mathrm{~min}$ on ice. After centrifugation as above, $400 \mu \mathrm{L}$ of the supernatant was transferred into wells of a 1-mL 96-well plate. Plasmid DNA was precipitated by addition of $280 \mu \mathrm{L}$ of isopropanol and centrifugation as above for $20 \mathrm{~min}$. The DNA precipitate was resuspended in $50 \mu \mathrm{L}$ of TE buffer and further purified by Sephacryl S-500 chromatography using a 96-well SilentScreen plate (Nalge Nunc Intl.).

High-throughput nucleotide sequencing reactions were performed in 96-well plates using a total reaction volume of $10 \mu \mathrm{L}$ containing $2.5 \mu \mathrm{L}$ of plasmid mini-preparation $(\sim 100$ to 500 ng DNA), $2 \mu \mathrm{L}$ DyeTerminator reaction mixture, $0.5 \mu \mathrm{L}$ of $3.2 \mu \mathrm{M}$ T3/T7 primer, and $1 \mu \mathrm{L}$ of $5 \times$ reaction buffer. Sequencing reactions were performed in a GeneAmp PCR System 9600/9700 Thermocycler (PE Biosystems) using the following reaction conditions: $95^{\circ} \mathrm{C}$ for $5 \mathrm{~min}$; then 30 cycles of $95^{\circ} \mathrm{C}$ for $30 \mathrm{sec}, 50^{\circ} \mathrm{C}$ for $10 \mathrm{sec}, 60^{\circ} \mathrm{C}$ for $4 \mathrm{~min}$; and finally cooling to $4^{\circ} \mathrm{C}$. Sequencing reactions were purified using Sephadex G-50 equilibrated with $\mathrm{H}_{2} \mathrm{O}$ in a 96-well filtration plate (Millipore) by centrifugation at $2200 \mathrm{rpm}$ for $5 \mathrm{~min}$ as described above. The purified sequencing reactions $(10 \mu \mathrm{L})$ were analyzed using an automated DNA sequencer (ABI Prism 3700 DNA Analyzer, PE Biosystems) according to the manufacturer's instructions. To finish PAC/BAC sequencing, bridging shotgun clones between contigs were identified using the Consed program (see below). The nucleotide sequences of bridging plasmid DNAs were completed using transposon insertion system and $\mathrm{PI}+/$ - primers (ABI). DNA sequences were deposited in GenBank under the following accession nos.: AY152827, AY152826, AY152828, AY152829, AY152825, and AY152836, for clones 186b21, 102h1, f20, f23, 463h11, $6 \mathrm{~B} 1, \mathbf{2 4 4 e 2}, \mathrm{f} 2, \mathrm{~g} 7$, and 160a17, respectively.

\section{DNA Sequence Analyses}

Raw data generated from the automated DNA sequencer were transferred to Biolims (ABI) in SunStation e3500 at the Advanced Biomedical Computing Center (ABCC) at NCIFrederick. A Phred base-calling program (Ewing and Green 1998; Ewing et al. 1998) was used to read all raw data. Nucleotide sequences were examined for vector and $E$. coli sequences, trimmed, and assembled by the Phrap program and then edited by the Consed program (Gordon et al. 1998). Automated sequence analyses were carried out using Sun e3500, DEC al- pha, SGI high-speed computers at the ABCC. These analyses included RepeatMasker (A. Smit and P. Green, unpubl.) for identification of mammalian repeat sequences, BLASTN (Altschul et al. 1990) for nucleotide sequence homology search in databases for every sequence data file and sequence contig, Genscan (Burge and Karlin 1997) for prediction of protein coding genes, and BLASTP (Gish and States 1993) for homology search of the Genscan-predicted peptide sequences for all genes in nucleotide sequences and contigs. The Dotter (Sonnhammer and Durbin 1995) dotplot program was used to compare any two large-scale nucleotide sequences. Assembly of PAC/BAC sequences was carried out based on a previous PAC/BAC contig map. Quality control was done using Autofinish program (Gordon et al. 2001) and primer extension protocol to obtain sequence with a quality value more than 30 .

\section{ACKNOWLEDGMENTS}

We thank Mary Carrington, Maureen Martin, and Xiaojiang Gao for suggestions and review of the manuscript. This publication was funded in whole or in part with Federal funds from the National Cancer Institute, NIH, under contract No. N01-C0-12400.

The publication costs of this article were defrayed in part by payment of page charges. This article must therefore be hereby marked "advertisement" in accordance with 18 USC section 1734 solely to indicate this fact.

\section{REFERENCES}

Altschul, S.F., Gish, W., Miller, W., Myers, E.W., and Lipman, D.J. 1990. Basic local alignment search tool. J. Mol. Biol. 215: $403-410$.

Andrew, S.E. 2000. Feline infectious peritonitis. Vet. Clin. North Am. Small Anim. Pract. 30: 987-1000.

Beck, T., Menninger, J., Voigt, G., Newmann, K., Nishigaki, Y., Nash, W.G., Stephens, R.M., Wang, Y., de Jong, P.J., O'Brien, S.J., et al. 2001. Comparative feline genomics: A BAC/PAC contig map of the major histocompatibility complex class II region. Genomics 71: $282-295$.

Bernardi, G. 2000a. Isochores and evolutionary genomes of vertebrates. Gene 241: 3-17.

. 2000b. The compositional evolution of vertebrate genomes. Gene 259: 31-43.

Burge, C. and Karlin, S. 1997. Prediction of complete gene structures in human genomic DNA. J. Mol. Biol. 268: 78-94.

Carrington, M., Nelson, G.W., Martin, M.P., Kissner, T., Vlahov, D., Goedert, J.J., Kaslow, R., Buchbinder, S., Hoots, K., and O'Brien, S.J. 1999. HLA and HIV-1: Heterozygote advantage and B*35-Cw*04 disadvantage. Science 283: 1748-1752.

Daniels, G.R. and Deininger, P.L. 1985. Repeat sequence families derived from mammalian tRNA genes. Nature 317: 819-822.

Doherty, P.C. and Zinkernagel, R.M. 1976. Specific immune lysis of paramyxovirus infected cells by $\mathrm{H}-2$-compatible, thymus-derived lymphocytes. Immunology 31: 27-32.

Eizirik, E., Murphy, W.J., and O'Brien, S.J. 2001. Molecular dating and biogeography of the early placental mammal radiation. $J$. Hered. 92: 212-219.

Ewing, B. and Green, P. 1998. Base-calling of automated sequencer traces using phred. II. Error probabilities. Genome Res. 8: $186-194$.

Ewing, B., Hillier, L., Wendl, M.C., and Green, P. 1998. Base-calling of automated sequencer traces using phred. I. Accuracy assessment. Genome Res. 8: 175-185.

Gish, W. and States, D.J. 1993. Identification of protein coding regions by database similarity search. Nat. Genet. 3: 266-272.

Gordon, D., Abajian, C., and Green, P. 1998. Consed: A graphical tool for sequence finishing. Genome Res. 8: 195-202.

Gordon, D., Desmarais, C., and Green, P. 2001. Automated finishing with autofinish. Genome Res. 11: 614-625.

Hoover, E.A. and Mullins, J.I. 1991. Feline leukemia virus infection and diseases. J. Am. Vet. Med. Assoc. 199: 1287-1297.

Hughes, A.L. and Yeager, M. 1998. Natural selection at major histocompatibility complex loci of vertebrates. Annu. Rev. Genet. 32: 415-435.

Johnson, W.E. and O'Brien, S.J. 1997. Phylogenetic reconstruction of

\section{Genome Research


the Felidae using $16 \mathrm{~S}$ rRNA and NADH-5 mitochondrial genes. J. Mol. Evol. 44: 98-116.

Kaufman, J., Milne, S., Gobel, T.W., Walker, B.A., Jacob, J.P, Auffray, C., Zoorob, R., and Beck, S. 1999. The chicken B locus is a minimal essential major histocompatibility complex. Nature 401: 923-925.

Klein, J. 1986. Natural history of the major histocompatibility complex. J. Wiley, New York.

The MHC sequencing consortium. 1999. Complete sequence and gene map of a human major histocompatibility complex. Nature 401: 921-923.

Murphy, W.J., Sun, S., Chen, Z., Yuhki, N., Hirschmann, D., Menotti-Raymond, M., and O'Brien, S.J. 2000. A radiation hybrid map of the cat genome: Implications for comparative mapping. Genome Res. 10: 691-702.

Ng, W.L., Schummer, M., Cirisano, F.D., Baldwin, R.L., Karlan, B.Y., and Hood, L.1996. High-throughput plasmid mini preparations facilitated by micro-mixing. Nucleic Acids Res. 24: 5045-5047.

Nizetic, D., Figueroa, F., Dembic, Z., Nevo, E., and Klein, J. 1987. Major histocompatibility complex gene organization in the mole rat Spalax ehrenbergi: Evidence for transfer of function between class II genes. Proc. Natl. Acad. Sci. 84: 5828-5832.

O'Brien, S.J., Wienberg, J., and Lyons, L.A. 1997. Comparative genomics: Lessons from cats. Trends Genet. 13: 393-399.

O'Brien, S.J., Menotti-Raymond, M., Murphy, W.J., Nash, W.G., Wienberg, J., Stanyon, R., Copeland, N.G., Jenkins, N.A., Womack, J.E., and Marshall Graves, J.A. 1999. The promise of comparative genomics in mammals. Science 286: 479-481.

Parham, P. and Ohta, T. 1996. Population biology of antigen presentation by MHC class I molecules. Science 272: 67-74.

Pavlicek, A., Clay, O., Jabbari, K., Paces, J., and Bernardi, G. 2002. Isochore conservation on human chromosome 6 and mouse chromosome 17. FEBS Lett. 511: 175-177.

Pecon-Slattery, J. and O'Brien, S.J. 1998. Patterns of Y and X chromosome DNA sequence divergence during the Felidae radiation. Genetics 148: 1245-1255.

Pedersen, N.C., Ho, E.W., Brown, M.L., and Yamamoto, J.K. 1987. Isolation of a T-lymphotropic virus from domestic cats with an immunodeficiency-like syndrome. Science 235: 790-793.

Pollack, M.S., Mastrota, F., Chin-Louie, J., Monney, S., and Hayes, A. 1982. Preliminary studies of the feline histocompatibility system. Immunogenetics 16: 339-347.

Rowold, D.J. and Herrera, R.J. 2000. Alu elements and the human genome. Genetica 108: 57-72.

Schwartz, S., Zhang, Z., Frazer, K.A., Smit, A., Riemer, C., Bouck, J., Gibbs, R., Hardison, R., and Miller, W. 2000. PipMaker-A web server for aligning two genomic DNA sequences. Genome Res. 10: $577-586$.

Shiina, T., Tamiya, G., Oka, A., Takishima, N., Yamagata, T., Kikkawa, E., Iwata, K., Tomizawa, M., Okuaki, N., Kuwano, Y., et al. 1999. Molecular dynamics of MHC genesis unraveled by sequence analysis of the 1,796,938-bp HLA class I region. Proc. Natl. Acad. Sci. 96: 13282-13287.

Simonaro, C.M., Haskins, M.E., Abkowitz, J.L., Brooks, D.A., Hopwood, J.J., Zhang, J., and Schuchman, E.H. 1999. Autologous transplantation of retrovirally transduced bone marrow or neonatal blood cells into cats can lead to long-term engraftment in the absence of myeloablation. Gene Ther. 6: 107-113.

Slattery, J.P., Murphy, W.J., and O'Brien, S.J. 2000. Patterns of diversity among SINE elements isolated from three Y-chromosome genes in carnivores. Mol. Biol. Evol. 17: 825-829.

Smit, A.F. 1999. Interspersed repeats and other mementos of transposable elements in mammalian genomes. Curr. Opin. Genet. Dev. 9: 657-663.

Sonnhammer, E.L. and Durbin, R. 1995. A dot-matrix program with dynamic threshold control suited for genomic DNA and protein sequence analysis. Gene 167: 1-10.

Stephens, R., Horton, R., Humphray, S., Rowen, L., Trowsdale, J., and Beck, S. 1999. Gene organization, sequence variation and isochore structure at the centromeric boundary of the human MHC. J. Mol. Biol. 291: 789-799.

Stone, R.T. and Muggli-Cockett, N.E. 1990. Partial nucleotide sequence of a novel bovine major histocompatibility complex class II $\beta$-chain gene, BoLA-DIB. Anim. Genet. 21: 353-360.

Sun, H., Yang, M., Haskins, M.E., Patterson, D.F., and Wolfe, J.H. 1999. Retrovirus vector-mediated correction and cross-correction of lysosomal $\alpha$-mannosidase deficiency in human and feline fibroblasts. Human Gene Ther. 10: 1311-1319.

Takada, T., Kumánovics, A., Amadou, C., Yoshino, M., Jones, E.P., Athanasiou, M., Evans, G.A., and Fischer-Lindahl, K. 2003 Species-specific class I gene expansions formed the telomeric 1 $\mathrm{mb}$ of the mouse major histocompatibility complex. Genome Res. 13: $589-600$.

Takahashi, K., Rooney, A.P., and Nei, M. 2000. Origins and divergence times of mammalian class II MHC gene clusters. $J$. Hered. 91: 198-204.

van der Poel, J.J., Groenen, M.A., Dijkhof, R.J., Ruyter, D., and Giphart, M.J. 1990. The nucleotide sequence of bovine MHC ckass II $\alpha$ genes: DRA, DOA, and DYA. Immunogenetics 31: 29-36.

Verhoeven, A.J., Roos, M.H., and Ploegh, H.L. 1988. A feline class II $\alpha$ gene with striking similarity to the HLA-DPA pseudogene. Immunogenetics 28: 406-411.

Winkler, C., Schultz, A., Cevario, S., and O'Brien, S.J. 1989. Genetic characterization of FLA, the cat major histocompatibility complex. Proc. Natl. Acad. Sci. 86: 943-947.

Wright, H., Ballingall, K.T., and Redmond, J. 1994. The DY sub-region of the sheep MHC contains an A/B gene pair. Immunogenetics 40: 230-234

Yu, C.Y., Yang, Z., Blanchong, C.A., and Miller, W. 2000. The human and mouse MHC class III region: A parade of 21 genes at the centromeric segment. Immunol. Today 21: 320-328.

Yuhki, N. and O'Brien, S.J. 1988. Molecular characterization and genetic mapping of class I and class II MHC genes of the domestic cat. Immunogenetics 27: 414-425.

Yuhki, N. and O'Brien, S.J. 1997. Nature and origin of polymorphism in feline MHC class II $D R A$ and $D R B$ genes. $J$. Immunol. 158: 2822-2833.

Zinkernagel, R.M. 1996. Immunology taught by viruses. Science 271: $173-178$.

\section{WEB SITE REFERENCES}

http://www.angis.org.au/Databases/BIRX; OMIM Database used to search feline hereditary diseases.

Received November 8, 2002; accepted in revised form March 5, 2003.
Genome Research www.genome.org 